\title{
Is the Sevier Desert reflection of west-central Utah a normal fault?
}

\author{
Mark H. Anders 7. Department of Geological Sciences and Lamont-Doherty Earth Observatory of Columbia University, \\ Nicholas Christie-Blick J Palisades, New York 10964-8000
}

\begin{abstract}
A prominent west-dipping reflection that can be traced in seismic-reflection profiles over an area of $7000 \mathrm{~km}^{2}$ beneath the Sevier Desert basin of west-central Utah is generally referred to as the Sevier Desert detachment and is widely regarded as one of the best examples of an upper-crustal low-angle normal fault. The absence of evidence for fault-related deformation in drill cuttings and core from two industry boreholes that intersect this feature casts doubt on the fault interpretation. The existing interpretation is based mainly on the observation that highangle normal faulting is restricted largely to Tertiary sedimentary and volcanic rocks above the reflection. An alternative explanation is that the high-angle faults are related to the withdrawal of early deposited lacustrine salt, which even today is as much as $\mathbf{2} \mathbf{~ k m}$ thick. Reevaluation of the seismic data suggests that the Sevier Desert reflection consists of two spatially and genetically distinct segments: a shallow segment here interpreted as an unconformity between Paleozoic and Tertiary strata and a fortuitously aligned deeper segment that is traceable to mid- and lowercrustal levels and that appears to represent a thrust fault related to the Cretaceous Sevier orogeny.
\end{abstract}

\section{INTRODUCTION}

The geologic community is divided as to whether normal faults with dips of $<20^{\circ}$ can be active in the upper crust (Wernicke, 1981, 1992; Allmendinger et al., 1983; Axen, 1993; John and Foster, 1993) or whether they form at high angles and are subsequently rotated to lower angles during continued deformation (Davis, 1983; Spencer, 1984; Buck, 1988; Hamilton, 1988; Wernicke and Axen, 1988). Jackson (1987) studied a large number of earthquake focal mechanisms from normal faults and concluded that none could be attributed confidently to slip on low-angle structures. Abers (1991) interpreted a single earthquake in eastern Papua New Guinea in terms of slip on a subsurface continuation of a detachment fault associated with a metamorphic core complex in the D'Entrecasteaux extensional province, but his conclusions are equivocal. Sibson (1985) argued that the frictional resistance of an uppercrustal low-angle normal fault is too great to permit movement. In contrast, Axen (1992) suggested that frictional resistance might be overcome under conditions of elevated pore-fluid pressure (cf. Scholz, 1992). Recognizing the apparent paradox of uppercrustal normal faulting, several authors have concluded that low-angle normal faults develop in the upper crust only under special conditions (e.g., Forsyth, 1992; Parsons and Thompson, 1993) and that, unless these conditions exist, extension is accommodated by high-angle normal faults, with dips flattening only below the brittle-ductile transition region (e.g., Miller et al., 1983; Lister and Davis, 1989; Melosh, 1990; Lister and Baldwin, 1993).

Commonly cited as evidence in support of the notion that slip can take place on uppercrustal low-angle normal faults is a promi- nent reflection observed in seismic-reflection profiles across the Sevier Desert basin of west-central Utah (Fig. 1). The reflection, which dips westward at about $11^{\circ}$ and can be traced in scismic data over an area of 7000 $\mathrm{km}^{2}$, was first interpreted as a detachment fault by McDonald (1976), and this idea has been accepted in subsequent studies (Wernicke, 1981, 1985; Allmendinger et al., 1983, 1985; Von Tish et al., 1985; Planke and Smith, 1991) despite the fact that the "fault" is everywhere buried beneath the Sevier Desert basin. According to McDonald (1976), the reflection corresponds to a Sevier-age (Cretaceous) thrust decollement that subsequently underwent backsliding of the hanging wall after the cessation of shortening, a process that has been shown to have taken place in the nearby Wyoming segment of the thrust belt (Lamerson, 1982; West, 1992). Wernicke $(1981,1985)$ used the Sevier Desert reflection as a model for the early stages of unroofing of metamorphic core complexes, in which the hanging wall slides back on a flat surface, breaks into a series of domino-style blocks and exposes midcrustal rocks of the footwall. On the basis of seismic data acquired by COCORP (Consortium for Continental Reflection Profiling) in the early $1980 \mathrm{~s}$, and in contrast to McDonald (1976), Allmendinger et al. (1983) and Von Tish et al. (1985) concluded that the normal faulting was not influenced by the location of Sevier thrust faults. By matching apparently offset features in hanging-wall and footwall blocks, they estimated that as much as 38 $\mathrm{km}$ of displacement had occurred on the supposed detachment since the late Oligocene. Planke and Smith (1991) obtained a significantly smaller estimate of 5.5 to 7.2 $\mathrm{km}$ by dividing the cross-sectional area of the Sevier Desert basin by the maximum depth (12 to $15 \mathrm{~km})$ to which the reflection can be traced. Unfortunately, the assumption of mass balance implied in the technique they used is not maintained. Thus, if the fault interpretation is correct, the best estimate of displacement remains that of Von Tish et al. (1985), and this is the one addressed in this paper.

All of these interpretations were based mainly on the fact that, in the seismic-reflection data, high-angle normal faulting is largely restricted to Tertiary sedimentary and volcanic rocks above the reflection; few if any of these faults appear to offset the reflection itself. However, none of the published interpretations involved direct observation of the supposed detachment surface. New evidence summarized in this paper now casts doubt on the fault interpretation and indicates that over large areas the reflection may instead be due to an unconformity.

\section{LOCATION OF THE SEVIER DESERT REFLECTION IN BOREHOLES}

In considering the origin of the Sevier Desert reflection, perhaps the most important issue concerns the precise correlation of the reflection to the geology encountered in available boreholes. Over large areas, the reflection appears to correspond to the Paleozoic-Tertiary contact, a surface that is associated with a marked change in acoustic impedance (the product of density and seismic velocity). The fault interpretation can therefore be tested by examining this contact, as long as the sites chosen exclude the possibility of intersecting rider blocks of $\mathrm{Pa}$ leozoic rocks that might locally be present above a detachment fault. The Sevier Desert reflection is penetrated by a number of boreholes drilled in the course of oil and gas exploration in the late 1970 s and early 1980 s (Sharp, 1984; Planke and Smith, 1991). Recently, we obtained cuttings and core from the ARCO Hole-in-the-Rock and ARCO Meadow Federal \#1 exploration wells (AHR and AMF \#1), courtesy of ARCO. In both holes, the boundary is marked by a sharp decrease in the proportion of sandstone plus siltstone (Tertiary) and by a concomitant increase in the proportion of Paleozoic carbonate, which tends to be fossiliferous and oolitic (Fig. 2). The persistence of sandstone and siltstone in cuttings below the contact is attributed to caving. Sonic logs from the two boreholes reveal a marked increase in seismic velocity (and 


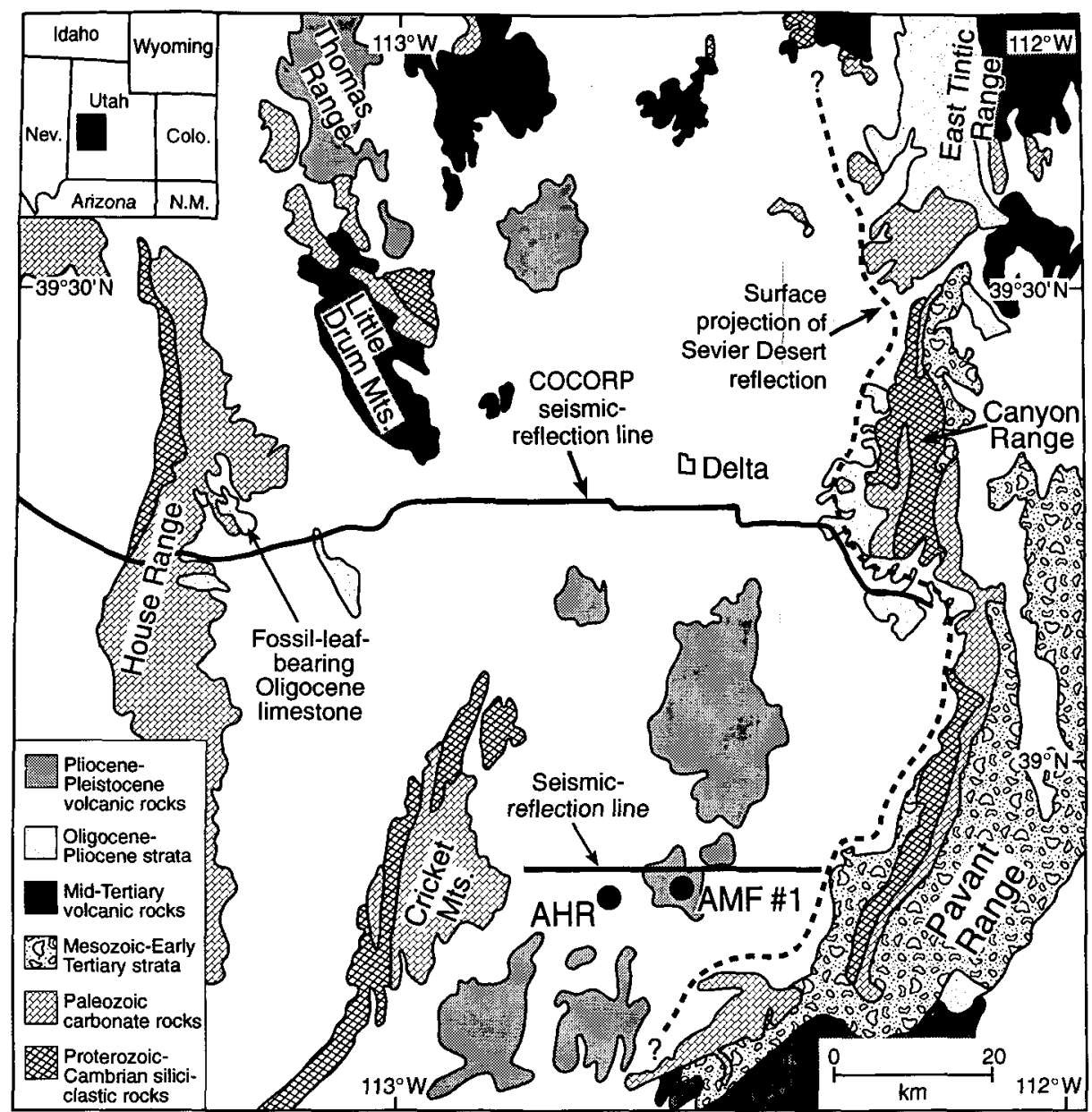

Figure 1. Generalized geologic map of Sevier Desert basin area, not including faults, modified from Allmendinger et al. (1983) and Planke and Smith (1991). Circles denote locations of two industry boreholes: ARCO Hole-in-the-Rock (AHR); and ARCO Meadow Federal \#1 (AMF \#1). Seismicreflection line from Planke and Smith (1991). COCORP seismic-reflection line from Allmendinger et al. (1983).

thus acoustic impedance) at the same horizon, confirming the inferred correlation with the seismic-reflection data. In AMF \#1, the velocity increases abruptly downward from $4.7 \mathrm{~km} / \mathrm{s}$ to $5.9 \mathrm{~km} / \mathrm{s}$. In AHR, it increases from $4.9 \mathrm{~km} / \mathrm{s}$ to $6.4 \mathrm{~km} / \mathrm{s}$ at the contact and then gradually increases over $35 \mathrm{~m}$ to 6.8 $\mathrm{km} / \mathrm{s}$.

\section{ABSENCE OF BRITTLE DEFORMATION}

Studies of microfracturing in sandstones near faults (e.g., Brock and Engelder, 1977; Anders and Wiltschko, 1994) have shown that microfracture density increases significantly within $3 \mathrm{~m}$ of a fault surface even for normal faults displaced as little as $2 \mathrm{~m}$. A pronounced increase in microfracturing would, therefore, be anticipated close to a fault with tens of kilometres of displacement. Thin sections of a series of samples recovered at $3 \mathrm{~m}$ intervals from the AHR and AMF \#1 boreholes were used to evaluate the level of deformation close to the Paleozoic-Tertiary contact. Microfracture density was assessed by using the microfracture index developed by Borg et al. (1960). In this technique, all microfractures are counted in 10 to 20 quartz grains per chip and in 18 chips per sampling interval. Grains are selected to be of approximately uniform size, and microfractures are counted with the same microscope ocular, because the assessment of microfractures is obviously influenced by grain size and magnification. Individual grains are binned according to the number of microfractures that they contain, on a scale that ranges from 100 (no microfractures) to 500 (totally smashed grain). For example, a microfracture index of 250 for a given sampling interval implies that, on average, each grain in the sample contains seven microfractures. In their study of the Muddy Mountains thrust of southern Nevada, a fault of large displacement but with a relatively narrow fault zone, Brock and Engelder (1977) determined a microfracture index of 250 from samples taken from within $3 \mathrm{~m}$ of the fault. The microfractures used in our study are "healed" or "partially healed" microfractures (see Kranz, 1983), features that are easily distinguishable from fractures induced by drilling.

Contrary to expectation, the microfracture index does not vary significantly with depth, and if anything decreases slightly as the Paleozoic-Tertiary contact is approached in both boreholes (Fig. 2). No smashed grains, angular fragments, or other signs of cataclasis are observed. Many grains within the siltstone and sandstone chips are characterized by undulose extinction, and in general the abundance of such grains increases downhole toward the contact, especially in AMF \#1. However, the fact that this trend is not matched by a corresponding change in the density of microfracturing indicates that the undulose extinction is inherited from an earlier deformational event, presumably the Sevier orogeny, and that the observed variation in the abundance of undulose grains is due solely to a change in provenance. Given that the present depth to the contact is the maximum depth of burial predicted by any of the faulting models, plastic deformation of quartz could not have taken place during the late Tertiary under any plausible geothermal gradient (Borg et al., 1960; Griggs et al., 1960). We conclude that the absence of significant deformation and the lack of variation in deformation in the vicinity of the $\mathrm{Pa}$ leozoic-Tertiary contact is not consistent with the existence of a fault with tens of kilometres of displacement. This is especially the case because the present geometry of blocks in the hanging wall of the supposed detachment implies significant beveling and cataclasis during displacement to accommodate an obvious space problem that arises in palinspastic reconstruction (see Sharp, 1984; Von Tish et al., 1985).

\section{OTHER EVIDENCE THAT CONFLICTS WITH EXISTING INTERPRETATIONS}

\section{Undeformed Ooids and Fossil Fragments}

Samples of Paleozoic carbonate rocks recovered from within $12 \mathrm{~m}$ of the contact with Tertiary sandstone in the AMF \#1 borehole contain undeformed ooids (see Kerr, 1993, for photomicrograph). A sample of limestone recovered in core from $15 \mathrm{~m}$ below the Paleozoic-Tertiary contact in borehole AHR contains undeformed trilobite fragments. The main expression of deformation is the presence of releasing-bend microfaults, features interpreted by Ferrill and Groshong (1993) to be characteristic of depths of deformation $<2.4 \mathrm{~km}$. In the detachment interpretation, Paleozoic rocks of the lower plate would have been at a depth of about 7 to $8 \mathrm{~km}$ at the time faulting began, and, given a plausible geothermal gradient, confining pressure, and strain rate, they should have 


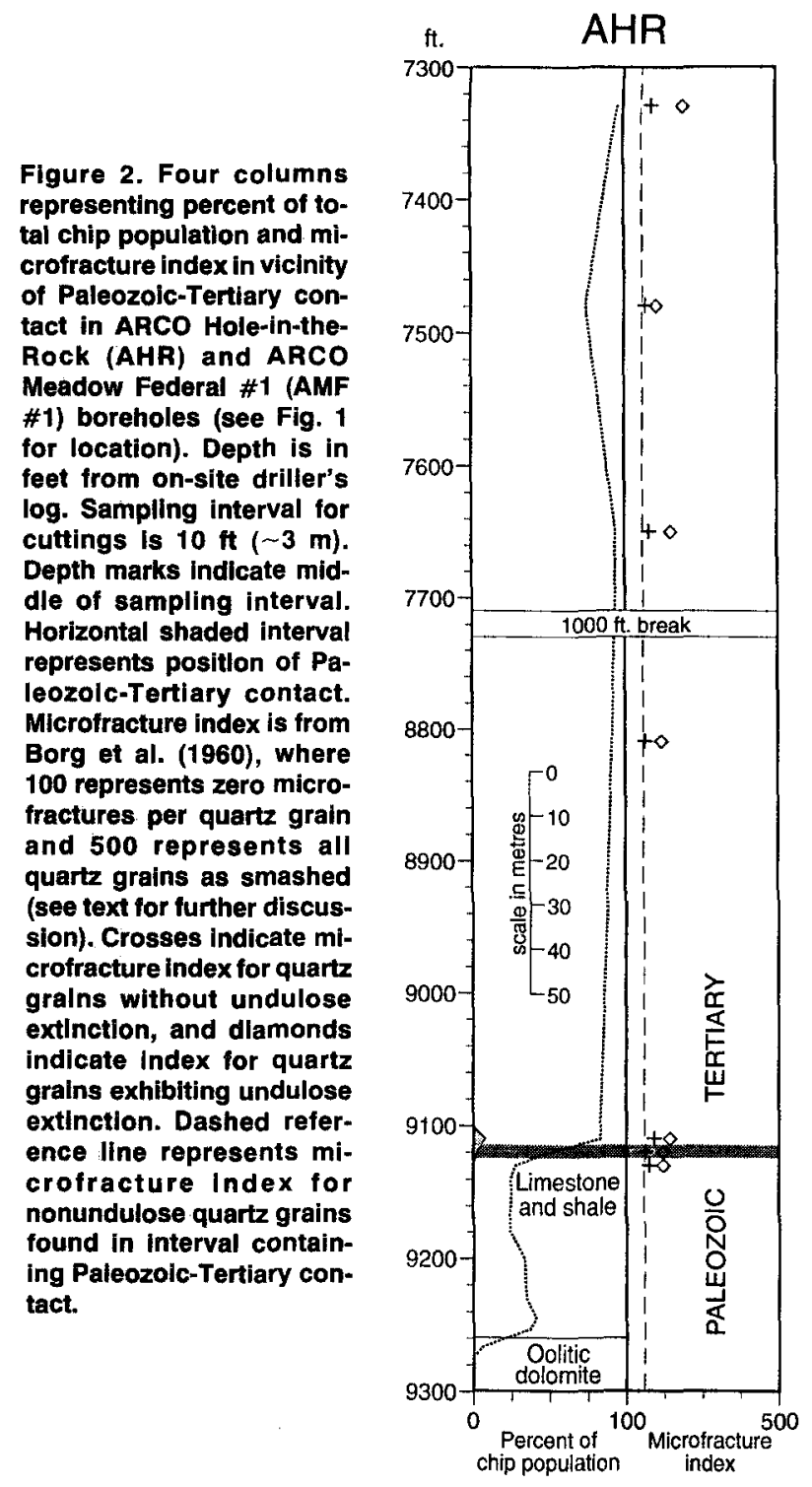

respond to an unconformity at which Tertiary sedimentary rocks rest in depositional contact on Paleozoic rocks. A second, deeper segment, observed only in the northern part of the Sevier Desert basin, appears to branch into several splays and is offset from the upper reflection. These splays are traceable to mid- and lower-crustal levels and may represent mylonite zones of Sevier age. Located above the lower reflection is an anticline, which we interpret as a ramp anticline associated with Sevier-aged thrusting (see Fig. 2 of Allmendinger et al., 1983).

The existence of an unconformity is supported by evidence for a basal conglomerate. In cuttings of uniform chip size, the proportion of chips composed entirely of a single particle of quartz, feldspar, quartzite, or volcanic rock fragments ought to reflect the grain size of the rocks from which the chips were derived. The fact that the abundance of single-particle chips increases downward toward the Paleozoic-Tertiary contact (see borehole AMF \#1 in Fig. 2) indicates a pronounced increase in grain size, in contrast to the decrease in grain size that might be anticipated if a fault were present (e.g., Brock and Engelder, 1977).

If the Sevier Desert reflection is due to the presence of an unconformity, it is necessary to explain the lack of significant offset by high-angle normal faults above it. The most reasonable possibility is that the high-angle faults are for the most part due to withdrawal of early deposited salt. The style of deformation is similar to that observed at passive continental margins known to be underlain by thick salt deposits (Harding and Lowell, 1979; Bally, 1983). One of the boreholes in the Sevier Desert basin penetrated a section of salt as much as $2 \mathrm{~km}$ thick (Planke and Smith, 1991) and several features observed in seismic sections can be interpreted as velocity pullups (see the central part of section \#8 of McDonald, 1976).

\section{Paleoelevation of the Supposed Hanging Wall}

Another piece of evidence that is difficult to accommodate in the fault interpretation is provided by freshwater lacustrine limestone of mid-Oligocene age that crops out in the House Range, along the western margin of the Sevier Desert basin in the assumed hanging-wall block (Fig. 1). The limestone contains gastropod shells (Helix and Lymnaea) and fossil leaves from poplar and willow trees (Hintze, 1981). In the palinspastic reconstruction of Sharp (1984) and Von Tish et al. (1985), rocks in the hanging wall are restored to an elevation as much as $7 \mathrm{~km}$ $(23,000 \mathrm{ft}$.) higher than rocks that are today at about the same elevation in the footwall. Alluvial conglomerate of early Oligocene age (>32 Ma; Campbell, 1979) that crops out in the Canyon Range in the footwall block must have been deposited above sea level. So no matter what assumptions are made about isostatic compensation, the reconstruction implies that the limestone accumulated at an elevation higher than might be expected for the associated flora (K. M. Gregory, 1994, personal commun.). This difficulty can be resolved only if the total displacement on the inferred detachment is considerably less than the maximum $38 \mathrm{~km}$ proposed by Sharp (1984) and Von Tish et al. (1985).

\section{AN ALTERNATIVE HYPOTHESIS}

In view of these difficulties, and elaborating on ideas presented by Anders (1993), we propose an alternative interpretation for the Sevier Desert reflection, one that does not involve displacement along this feature during Tertiary time. We suggest that the reflection consists of two spatially and genetically distinct segments that are fortuitously aligned. The main segment is thought to cor-

\section{CONCLUSIONS}

Borehole samples obtained from levels close to the depth of the Sevier Desert reflection in west-central Utah exhibit no significant fault-related deformation, and this casts doubt on the widely held view that the reflection represents a regional detachment fault with as much as $38 \mathrm{~km}$ of displacement. Reevaluation of the seismic data suggests that the reflection consists of two distinct segments, the most important of which is an unconformity between Paleozoic and Tertiary strata. This alternative hypothesis can be tested by means of scientific drilling in the Sevier Desert basin.

\section{ACKNOWLEDGMENTS \\ Supported by National Science Foundation grant EAR 93-05175 to Anders. Access to cuttings}


and core material was generously provided by ARCO. We thank S. Wills, A. E. Holmes, S. Krueger, and $M$. Anders for assistance in preparation of the paper, and A. W. Snoke and an anonymous reviewer for helpful comments on the manuscript. Lamont-Doherty Earth Observatory contribution number 5224 .

\section{REFERENCES CITED}

Abers, G. A., 1991, Possible seismogenic shallowdipping normal faults in the WoodlarkD'Entrecasteaux extensional province, Papua New Guinea: Geology, v. 19, p. 1205-1208.

Allmendinger, R. W., Sharp, J. W., Von Tish, D., Serpa, L., Brown, L., Kaufman, S., Oliver, J., and Smith, R. B., 1983, Cenozoic and Mesozoic structure of the eastern Basin and Range province, Utah, from COCORP seismic-reflection data: Geology, v. 11, p. 532-536.

Allmendinger, R. W., Sharp, J., Von Tish, D., Oliver, J., and Kaufman, S., 1985, A COCORP crustal-scale seismic profile of the Cordilleran hingeline, eastern Basin and Range province, in Gries, R. R., and Dyer, R. C., eds., Seismic exploration of the Rocky Mountain region: Denver, Rocky Mountain Association of Geologists and Denver Geophysical Society, p. 23-30.

Anders, M. H., 1993, The Sevier Desert detachment of west-central Utah: Is it a normal fault?: Geological Society of America Abstracts with Programs, v. 25, no. 6, p. A475.

Anders, M. H., and Wiltschko, D. V., 1994, Microfracturing, paleostress and the growth of faults: Journal of Structural Geology, v. 16, p. $795-815$

Axen, G. J., 1992, Pore pressure, stress increase, and fault weakening in low-angle normal faulting: Journal of Geophysical Research, v. 97 , p. $8979-8991$.

Axen, G. J., 1993, Ramp-flat detachment faulting and low-angle normal reactivation of the Tule Springs thrust, southern Nevada: Geological Society of America Bulletin, v. 105, p. 1076-1090.

Bally, A. W., ed., 1983, Seismic expression of structural styles: American Association of Petroleum Geologists Studies in Geology 15, v. 2.

Borg, I., Friedman, M., Handin, J., and Higgs, D. V., 1960, Experimental deformation of St. Peter Sand: A study of cataclastic flow, in Griggs, D., and Hardin, J., eds., Rock deformation: Geological Society of America Memoir 79, p. 133-191.

Brock, W. G., and Engelder, T., 1977, Deformation associated with the movement of the Muddy Mountain overthrust in the Buffington window, southeastern Nevada: Geological Society of America Bulletin, v. 88, p. $1667-1677$.

Buck, W. R., 1988, Flexural rotation of normal faults: Tectonics, v. 7, p. 959-973.

Campbell, J. A., 1979, Middle to late Cenozoic stratigraphy and structural development of the Canyon Range, central Utah: Utah Geology, v. 6, p. 1-16.

Davis, G. H., 1983, Shear-zone model for the origin of metamorphic core complexes: Geology, v. 11, p. 342-347.
Donath, F. A., Faill, R. T., and Tobin, D. G., 1971, Deformational mode fields in experimentally deformed rock: Geological Society of America Bulletin, v. 82, p. 1441-1462.

Ferrill, D. A., and Groshong, R. H., Jr., 1993, Deformation conditions in the northern Subalpine Chain, France, estimated from deformation modes in coarse-grained limestone: Journal of Structural Geology, v. 15, p. $995-1006$.

Forsyth, D. W., 1992, Finite extension and lowangle normal faulting: Geology, v. 20, p. 27-30.

Griggs, D. T., Turner, F. J., and Heard, H. C., 1960, Deformation of rocks at $500^{\circ}$ to $800^{\circ} \mathrm{C}$, in Griggs, D., and Handin, J., eds., Rock deformation: Geological Society of America Memoir 79, p. 39-104.

Hamilton, W., 1988, Tectonic setting and variations with depth of some Cretaceous and $\mathrm{Ce}$ nozoic structural and magmatic systems of the western United States, in Ernst, W. G., ed., Metamorphism and crustal evolution of the western United States: Rubey Volume VII: Englewood Cliffs, New Jersey, Prentice-Hall, p. 1-40.

Handin, J., Higgs, D. V., and O'Brien, J. K., 1960, Torsion of Yule Marble under confining pressure, in Griggs, D., and Handin, J., eds., Rock deformation: Geological Society of America Memoir 79, p. 245-274.

Harding, T. P., and Lowell, J. D., 1979, Structural styles, their plate-tectonic habitats, and hydrocarbon traps in petroleum provinces: American Association of Petroleum Geologists Bulletin, v. 63, p. 1016-1058.

Hintze, L. F., 1981, Preliminary geologic map of the Marjum Pass and Swasey Peak SW quadrangles, Millard County, Utah: U.S. Geological Survey Miscellaneous Field Studies Map MF-1332, scale 1:24,000.

Jackson, J. A., 1987, Active normal faulting and crustal extension, in Coward, M. P., et al., eds., Continental extensional tectonics: Geological Society of London Special Publication 28, p. 3-17.

John, B. E., and Foster, D. A., 1993, Structural and thermal constraints on the initiation angle of detachment faulting in the southern $\mathrm{Ba}$ sin and Range: The Chemehuevi Mountains case study: Geological Society of America Bulletin, v. 105, p. 1091-1108.

Kerr, R. A., 1993, Geologists get together to dissect Earth's thin skin: Science, v. 262, p. 992-993.

Kranz, R. L., 1983, Microcracks in rocks: A review: Tectonophysics, v. 100, p. 449-480.

Lamerson, P. R., 1982, The Fossil Basin and its relationship to the Absaroka thrust system, Wyoming and Utah, in Powers, R. B., ed., Geologic studies of the Cordilleran thrust belt: Denver, Rocky Mountain Association of Geologists, p. 279-340.

Lister, G. S., and Baldwin, S. L., 1993, Plutonism and the origin of metamorphic core complexes: Geology, v. 21, p. 607-610.

Lister, G. S., and Davis, G. A., 1989, The origin of metamorphic core complexes and detachment faults formed during Tertiary continental extension in northern Colorado River region, U.S.A.: Journal of Structural Geology, v. 11, p. 65-94.
McDonald, R. E., 1976, Tertiary tectonics and sedimentary rocks along the transition: Basin and Range province to plateau and thrust belt province, Utah, in Hill, J. G., ed., Symposium on geology of the Cordilleran hingeline: Denver, Rocky Mountain Association of Geologists, p. 281-317.

Melosh, H. J., 1990, Mechanical basis for lowangle normal faulting in the Basin and Range province: Nature, v. 343 , p. 331-335.

Miller, E. L., Gans, P. B., and Garing, J., 1983, The Snake Range décollement: An exhumed mid-Tertiary ductile-brittle transition: Tectonics, v. 2, p. 239-263.

Parsons, T., and Thompson, G. A., 1993, Does magmatism influence low-angle normal faulting?: Geology, v. 21, p. 247-250.

Planke, S., and Smith, R. B., 1991, Cenozoic extension and evolution of the Sevier Desert basin, Utah, from seismic reflection, gravity, and well log data: Tectonics, v. 10, p. $345-365$.

Scholz, C. H., 1992, Weakness amidst strength: Nature, v. 359 , p. $677-678$.

Sharp, J. W., 1984, West-central Utah: Palinspastically restored sections constrained by $\mathrm{CO}$ CORP seismic reflection data [M.S. thesis]: Ithaca, New York, Cornell University, $60 \mathrm{p}$.

Sibson, R. H., 1985, A note on fault reactivation: Journal of Structural Geology, v. 7, p. 751-754.

Spencer, J. E., 1984, Role of tectonic denudation in warping and uplift of low-angle normal faults: Geology, v. 12, p. 95-98.

Von Tish, D. B., Allmendinger, R. W., and Sharp, J. W., 1985, History of Cenozoic extension in central Sevier Desert, west-central Utah, from COCORP seismic reflection data: American Association of Petroleum Geologists Bulletin, v. 69, p. 1077-1087.

Wernicke, B., 1981, Low-angle normal faults in the Basin and Range Province: Nappe tectonics in an extending orogen: Nature, v. 291 , p. $645-648$

Wernicke, B., 1985, Uniform-sense normal simple shear of the continental lithosphere: $\mathrm{Ca}-$ nadian Journal of Earth Sciences, v. 22, p. $108-125$.

Wernicke, B., 1992, Cenozoic extensional tectonics of the U.S. Cordillera, in Burchfiel, B. C., et al., eds., The Cordilleran orogen: Conterminous U.S.: Boulder, Colorado, Geological Society of America, Geology of North America, v. G-3, p. 553-581.

Wernicke, B., and Axen, G. J., 1988, On the role of isostasy in the evolution of normal fault systems: Geology, v. 16, p. 848-851.

West, M. W., 1992, An integrated model for seismogenesis in the intermountain seismic belt: Seismological Society of America Bulletin, v. 82 , p. $1350-1372$.

Manuscript received March 1, 1994

Revised manuscript received June 13, 1994 Manuscript accepted June 21, 1994 